\title{
BI DIGITAL PORTFOLIO FOR VARIOUS STORE FRONTS
}

\author{
Farhana Sethi ${ }^{1}$ \\ ${ }^{1}$ Global Data \& Analytics Business Intelligence -Quality \& Governance
}

October 26, 2020

\begin{abstract}
BI Portfolio central cataloging helps business users to understand what BI Assets an organization has, where it is located and what stories it tells. It helps to prioritize work and resources. BI portfolio provides a central place where all business intelligence assets are cataloged. It offers over 3000 BI Assets, each BI Asset is align with one or more Storefront mapped with various Categories, tags and Key processes.
\end{abstract}

\section{Hosted file}

IJISRR-266.pdf available at https://authorea.com/users/358660/articles/488807-bi-digitalportfolio-for-various-store-fronts 